\title{
AKTIVITAS ANTIOKSIDAN EKSTRAK DAUN BELIMBING HUTAN (CNESTIS PALALA(LOUR).MERR) ASAL KALIMANTAN TIMUR
}

\author{
Desy Apriati Ningsih ${ }^{1}$, Adam M. Ramadhan ${ }^{1}$, Rolan Rusli1, 2,* \\ ${ }^{1}$ Laboratorium Penelitian dan Pengembangan Kefarmasian "FARMAKA TROPIS" \\ Fakultas Farmasi, Universitas Mulawarman, Samarinda Kalimantan Timur, Indonesia \\ ${ }^{2}$ Kelompok Bidang Ilmu Kimia Farmasi, Fakultas Farmasi Universitas Mulawarman, \\ Samarinda, Kalimantan Timur, Indonesia \\ *E-mail: rolan@farmasi.unmul.ac.id
}

\begin{abstract}
ABSTRAK
Tumbuhan belimbing hutan (Cnestis palala(Lour).Merr) adalah salah satu tumbuhan Kalimantan Timur yang banyak digunakan oleh masyarakat asli kalimantan untuk mengatasi penyakit dalam. Namun belum ada bukti ilmiah yang menunjukkan manfaat dari tumbuhan ini. Oleh karena itu sebagai penelitian awal dilakukan penelitian kandungan metabolit sekunder dan aktivitas antioksidan pada bagian daun Belimbing Hutan. Penentuan aktivitas antioksidan dilakukan dengan menggunakan metode perendaman radikal bebas DPPH pada ekstrak methanol, fraksi n-heksana, fraksi etil asetat dan fraksi nbutanol. Hasil identifikasi golongan metabolit sekunder pada daun belimbing hutan adalah flavonoid, fenolik, tannin, dan steroid/terpenoid. Ekstrak dan fraksi daun belimbing hutan memiliki aktivitas antioksidan. Aktivitas antioksidan fraksi etil asetat sebanding dengan vitamin $\mathrm{C}$.
\end{abstract}

Kata Kunci: Aktivitas Antioksidan, Cnestis Palala.(Lour)Merr, DPPH, metabolit sekunder

\begin{abstract}
Cnestis palala(Lour).Merr is one of a Borneo plant that widely used by Borneo local people to cope with the disease. However, there is no scientific research showing the benefits of this plant. As an initial research is to determine secondary metabolites content and antioxidant activity of Cnestis palala(Lour).Merr leaves. The determination of antioxidant activities was used by DPPH free radicals in methanol extracts, $n$-hexane fraction, ethyl acetate fraction, and n-butanol fraction. The results of identification secondary metabolites Cnestis palala(Lour).Merr were flavonoids, phenols, tannins, and steroids/terpenoid. Extracts and fractions of Cnestis palala(Lour).Merr leaves have an antioxidant activity. Antioxidant activity of ethyl acetate fraction have a similar activity with Vitamin $C$.
\end{abstract}

Keywords: Antioxidant activity, Cnestis Palala.(Lour)Merr, DPPH, secondary metabolites

DOI: https://doi.org/10.25026/jsk.v2i1.99 


\section{PENDAHULUAN}

Tumbuhan belimbing hutan (Cnestis Palala.(Lour)Merr) banyak terdapat di dalam hutan dan pinggiran sungai mahakam. Tumbuhan ini digunakan oleh masyarakat Lokal Kalimantan Timur sebagai obat penyembuh penyakit dalam dan pengobatan pasca melahirkan. Bagian belimbing hutan yang sering digunakan mulai dari daun, akar, kulit batang hingga batangnya. Masyarakat dayak memanfaatkan batang maupun akar belimbing hutan dengan cara merebus kemudian meminum air rebusan secara rutin tiap hari. Berdasarkan kepercayaan masyarakat, belimbing hutan bersifat toksik, sehingga hal ini menarik untuk dikaji mengenai kandungan metabolit sekunder dan pemanfaatan aktivitas biologisnya.

\section{METODE PENELITIAN}

\section{Alat dan Bahan}

Peralatan yang digunakan adalah peralatan gelas yang biasa digunakan di Laboratorium, rotary evaporator, spektrofotometer UV-Vis, Timbangan analitik, Rotary Evaporator, spektrofotometer Uv-Vis, desikator, vortex, mikropipet, corong pisah.

Bahan tanaman yang digunakan dalam penelitian ini adalah bagian daun belimbing hutan. Tanaman ini sebelumnya diidentifikasi pada "Herbarium Mulawarman" Laboratorium Dendrologi dan Ekologi Hutan, Fakultas Kehutanan, Universitas Mulawarman. Daun belimbing hutan diambil di Kabupaten Kutai Barat, Kalimantan Timur. Pelarut yang digunakan dalam ekstraksi adalah metanol, $n$-heksana, etil asetat, dan n-butanol. Bahan kimia lainnya yang digunakan adalah asam klorida pekat, serbuk magnesium, besi (111) klorida, asam asetat glasial, asam asetat pekat, dan DPPH (2,2-diphenyl-1picrylhydrazil).

\section{Prosedur Kerja}

\section{Ekstraksi Sampel}

Daun belimbing hutan yang diambil adalah bagian daun yang masih utuh, hijau, segar, kemudian dikumpulkan dan dipisahkan dari tangkai dan pengotor. Setelah sampel ditimbang kembali, kemudian dicuci bersih dengan air mengalir untuk menghilangkan kotoran yang tersisa pada daun. Selanjutnya dipotong kecil-kecil, kemudian dikeringkan diudara terbuka yang terlindung dari cahaya matahari. Sampel yang telah kering diekstraksi dengan pelarut metanol dengan metode maserasi. Hasil maserasi dipisahkan antara filtrat dan residunya dengan penyaringan dan selanjutnya diuapkan pelarutnya dengan mengunakan rotary evaporator sehingga diperoleh ekstrak kental. Selanjutnya ekstrak diuapkan kemudian dikeringkan dengan menggunakan desikator. Kemudian ekstrak kasar metanol difraksinasi dengan metode fraksinasi cair-cair dengan menggunakan pelarut $n$-heksana, etil asetat, dan n-butanol.

\section{Identifikasi Metabolit Sekunder}

Identifikasi golongan metabolit sekunder dilakukan dengan cara mereaksikan reagen kimia spesifik kepada beberapa golongan senyawa metabolit sekunder yang terkandung didalam ekstrak maupun fraksi daun belimbing hutan.

\section{Aktivitas Antioksidan}

Pengujian aktivitas antioksidan dilakukan dengan cara mengambil $2 \mathrm{~mL}$ ekstrak dari masing-masing konsentrasi uji, kemudian ditambahkan dengan $2 \mathrm{~mL}$ larutan DPPH $40 \mathrm{ppm}$. Selanjutnya campuran larutan ini dihomogenkan dengan menggunakan vorteks dan dibiarkan ditempat gelap pada suhu kamar selama 30-45 menit. Kemudian larutan diukur absorbansinya dengan menggunakan Spektrofotometer UV- 
Visible pada panjang gelombang maksimum. Dari hasil absorbansi tersebut selanjutnya dihitung persen aktivitas antioksidan.

Perhitungan aktivitas antioksidan dengan menggunakan rumus :

$\%$ Aktivitas Antioksidan $=\frac{\text { Absorbansi blanko }- \text { Absorbansi sampel }}{\text { Absorbansi blanko }} \times 100 \%$

Tabel 1 Rendemen Ekstrak dan fraksi daun belimbing hutan

\begin{tabular}{lllll}
\hline No & Ekstrak & $\begin{array}{l}\text { Berat awal } \\
\text { (gram) }\end{array}$ & $\begin{array}{l}\text { Berat akhir } \\
\text { (gram) }\end{array}$ & $\begin{array}{l}\text { Rendemen } \\
(\%)\end{array}$ \\
\hline 1. & Simplisia daun & 3.000 & 1.200 & 40 \\
2. & Ekstrak Metanol & 330 & 44,2 & 13,3 \\
3. & Fraksi $n$-heksana & 20 & 7,1 & 35,5 \\
4. & Fraksi etil asetat & 20 & 2,7 & 13,5 \\
5. & Fraksi $n$-butanol & 20 & 6,1 & 30,5 \\
\hline
\end{tabular}

Tabel 2. Hasil Uji Metabolit Sekunder Daun Belimbing Hutan

\begin{tabular}{lllll}
\hline Metabolit Sekunder & \multicolumn{5}{c}{ Perlakuan } \\
\cline { 2 - 5 } & $\begin{array}{l}\text { Ekstrak } \\
\text { metanol }\end{array}$ & $\begin{array}{l}\text { Fraksi } n- \\
\text { heksana }\end{array}$ & $\begin{array}{l}\text { Fraksi etil } \\
\text { asetat }\end{array}$ & $\begin{array}{l}\text { Fraksi } n- \\
\text { butanol }\end{array}$ \\
\hline Steroid/Terpenoid & - & + & - & - \\
Alkaloid & - & - & - & - \\
Flavonoid & + & + & + & + \\
Fenolik & + & + & + & + \\
Saponin & - & - & - & - \\
Tanin & + & + & + & +
\end{tabular}

Keterangan : (-) Tidak Terdeteksi dan (+) Terdeteksi golongan senyawa

\section{HASIL DAN PEMBAHASAN}

Hasil perhitungan rendemen ekstrak dan fraksi daun belimbing hutan disajikan pada Tabel 1. Hasil pengujian metabolit sekunder menunjukkan bahwa pada bagian daun belimbing hutan terdapat golongan metabolit sekunder berupa flavonoid, fenolik, tanin, dan steroid/terpenoid. Hasil pengujian metabolit sekunder disajikan pada Tabel 2.

Pada pengujian alkaloid menggunakan pereaksi Mayer dengan hasil positif ditandai dengan terbentuknya endapan putih kekuningan sedangkan pereaksi dragendorff menghasilkan endapan jingga, penambahan asam klorida bertujuan untuk mengekstrak alkaloid yang bersifat basa dengan menggunakan larutan asam. Hasil uji metabolit sekunder menunjukan tidak adanya endapan, yang berarti bahwa ekstrak maupun fraksi daun belimbing hutan tidak mengandung senyawa alkaloid.

Pada pengujian flavonoid yang diuji menggunakan $\mathrm{Mg}$ dan $\mathrm{HCl}$ pekat. Hasil positif ditandai dengan terbentuknya warna merah, kuning atau jingga jika tereduksi dengan $\mathrm{Mg}$ dan $\mathrm{HCl}$. Pada uji flavonoid terbentuk warna kuning pada ekstrak metanol dan fraksi $n$-heksana, etil asetat dan $n$-butanol.

Pada pengujian fenol yang diuji dengan menggunakan $\mathrm{FeCl}_{3} 1 \%$ dengan hasil positif ditunjukkan dengan berwarna hitam. Berdasarkan hasil uji ekstrak metanol dan fraksi daun 
belimbing hutan positif mengandung senyawa fenol yang ditandai dengan perubahan warna hitam.

Pada pengujian saponin dengan hasil positif ditunjukkan dengan terbentujnya buih yang stabil setinggi 1$10 \mathrm{~cm}$ selama tidak kurang dari 10 menit.Saponin merupakan senyawa aktif permukaan yang mudah terdeteksi melalui kemampuannya dalam membentuk busa. Komponen ikatan glikosida yang terdapat didalam saponin menyebabkan senyawa ini cenderung bersifat polar. Berdasarkan hasil skrining fitokimia menunjukan ekstrak metanol dan fraksi $n$-heksana, etil asetat dan $n$ butanol daun belimbing hutan tidak terdapat saponin karena tidak membentuk busa (Febrina, Rusli, \& Muflihah, 2015).

Pada pengujian tanin dilakukan melalui penambahan $\mathrm{FeCl}_{3} 10 \%$ akan terjadi perubahan warna seperti biru tua atau hiaju kehitaman yang menandakan adanya senyawa tanin. Senyawa tanin termasuk kedalam senyawa polifenol yang artinya senyawa yang memiliki bagian berupa fenolik. Berdasarkan pengujian ekstrak metanol dan fraksifraksi daun belimbing hutan, diperoleh hasil warna hijau kehitaman yang menandakan positif terdapat senyawa tannin (Febrina et al., 2015).

Pada pengujian steroid/tripernoid menggunakan metode LiebermannBucchard yang nantinya akan memberikan warna jingga atau ungu untuk terpenoid dan warna biru untuk steroid.Uji ini didasarkan pada kemampuan senyawa triterpenoid dan steroid membentuk warna oleh $\mathrm{H}_{2} \mathrm{SO}_{4}$ pekat pada pelarut asetat glasial yang membentuk warna jingga. Bedasarkan hasil skrining fitokimia, dapat diketahui dari pengujian bahwa ekstrak metanol dan fraksi etil asetat dan fraksi $n$-butanol menandakan negatif untuk senyawa steroid maupun senyawa tripernoid sedangkan untuk fraksi $n$-heksana menandakan positif pada senyawa steroid yang ditunjukkan dengan adanya warna biru (Herman, 2013).

\section{Aktivitas Antioksidan}

Aktivitas antioksidan adalah kemampuan ekstrak dalam menangkap radikal bebas. Untuk mengetahui besarnya persentase peredaman radikal bebas oleh ekstrak maka dilakukan uji aktivitas antioksidan dengan metode peredaman radikal DPPH dengan parameter nilai $\mathrm{IC}_{50}$. Metode $\mathrm{DPPH}$ merupakan metode yang mudah, cepat dan murah dan berfungsi untuk mengukur elektron tunggal seperti aktivitas transfer elektron sekaligus juga untuk mengukur aktivitas penghambatan radikal bebas. Metode ini sangat cocok untuk skrining awal berbagai tumbuhan, termasuk ekstrak tumbuhan. Keberadaan sebuah antioksidan yang dapat menyumbang elektron kepada DPPH, menghasilkan warna kuning yang merupakan ciri spesifik dari radikal DPPH, radikal DPPH mempunyai absorbansi kuat pada panjang $517 \mathrm{~nm}$ dengan warna ungu yang khas (Es-Safi, Ghidouche, \& Ducrot, 2007) (Jagetia, Venkatesha, \& Reddy, 2003). Senyawa DPPH berwarna ungu karena adanya delokalisasi elektron pada atom nitrogen yang semula $(\mathrm{N}-\mathrm{N})$ menjadi $(\mathrm{N}=\mathrm{N})$ yang mengakibatkan ikatan rangkap terkonjugasi menjadi lebih panjang sehingga panjang gelombang DPPH bergeser ke panjang gelombang yang panjang. Peredaman tersebut dihasilkan oleh bereaksinya molekul difenil pikril hidrazil dengan atom hidrogen yang dilepaskan satu molekul komponen bahan uji sehingga membentuk senyawa difenil pikril hidrazin yang berwarna kuning.

Hasil perubahan warna dari ungu ke kuning sebanding dengan jumlah elektron yang ditangkap. Perubahan yang terjadi dapat diukur dengan spektrofotometri sinar tampak. Spektrofotometri merupakan alat untuk mengukur absorbansi atau transmitansi atau penyerapan suatu sampel. Semakin 
tinggi aktivitas suatu antioksidan suatu sampel maka semakin rendah absorbansi yang terbaca di spektrofotometri, hal ini dikarenakan semakin banyak terbentuknya difenilpikrilhidrazin sehingga yang terbaca di spektrofotometri adalah difenilpikrilhidrazil yang tersisa. Hal ini dikarenakan elektron yang tidak berpasangan pada DPPH memberikan absorbansi yang kuat pada spektrofotometri. Pada pengukuran absorbansi dari larutan sampel diukur pada panjang gelombang optimum. Dimana panjang gelombang optimum adalah panjang gelombang dimana daya absorbansinya paling tinggi. Campuran reaksi berupa larutan sampel dengan DPPH yang dilarutkan dalam metanol didiamkan selama 30 menit didalam ruangan gelap atau minim cahaya agar DPPH dapat tereduksi oleh sampel secara sempurna.

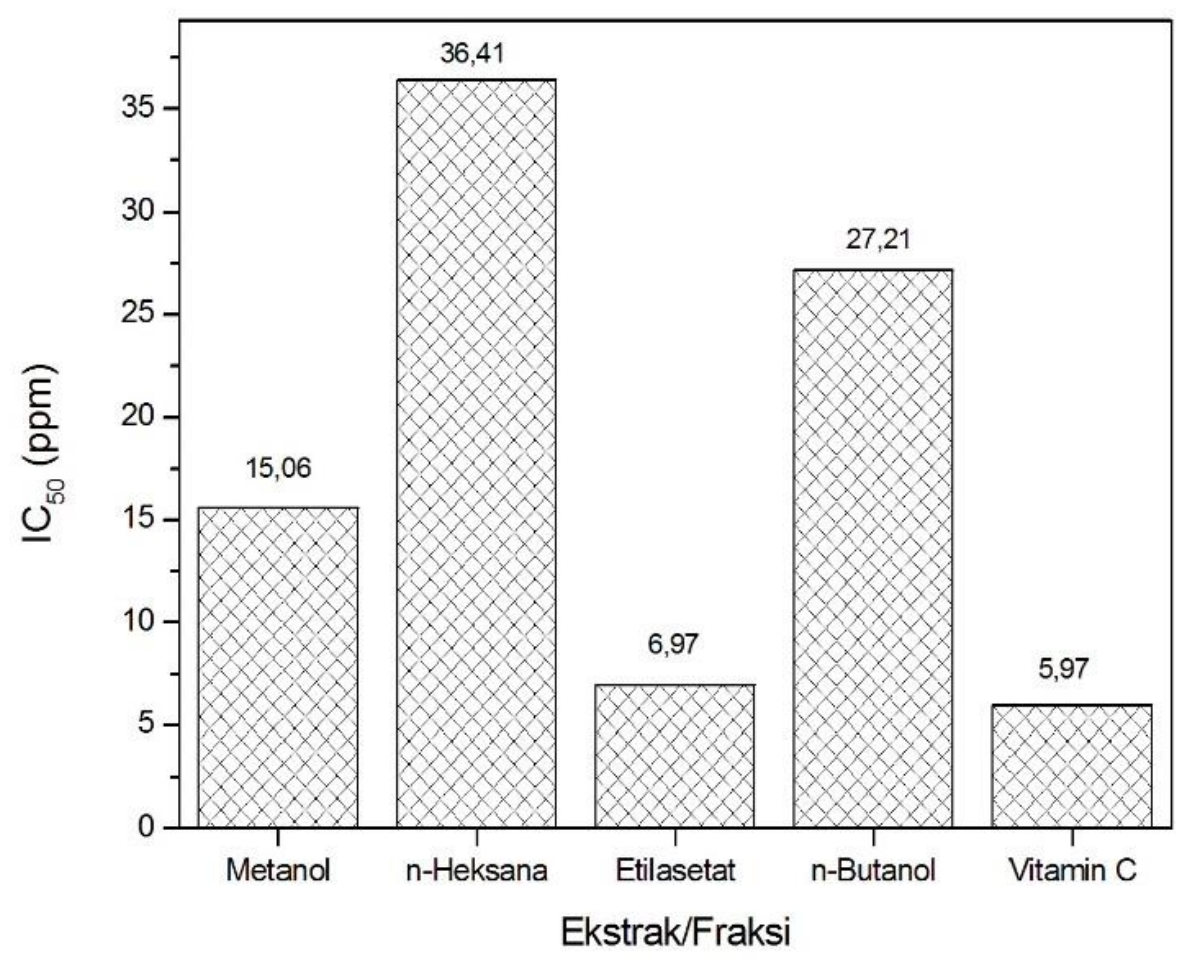

Gambar 1. Grafik Nilai IC50 ekstrak daun belimbing hutan dan vitamin C

Hasil pengukuran aktivitas antioksidan ekstrak metanol, fraksi nheksana, fraksi etil asetat, fraksi nbutanol dan vitamin $\mathrm{C}$, Berdasarkan pengujian aktivitas antioksidan yang telah dilakukan dapat disimpulkan bahwa $\mathrm{IC}_{50}$ dari ekstrak metanol, fraksi $n$ heksana, etil asetat dan $n$-butanol ialah sebesar 15,06 ppm, 34,61 ppm, 6,97 ppm dan 27,21 ppm, disajikan pada Gambar 1. Secara spesifik suatu senyawa dikatakan sebagai antioksidan jika nilai IC $_{50}$ kurang dari 200 ppm nilai $\mathrm{IC}_{50}$ dan jika yang diperoleh berkisar antara 200 sampai 1000 ppm, maka zat tersebut kurang aktif namun masih berpotensi sebagai zat antioksidan Semakin rendah nilai $\mathrm{IC}_{50}$ mengindikasikan aktivitas yang tinggi. $\mathrm{IC}_{50}$ kurang dari $50 \mathrm{ppm}$ sangat aktif atau kuat, sedangkan jika nilai $\mathrm{IC}_{50}$ berkisar 50 ppm sampai 100 ppm cukup aktif atau sedang, 100 ppm sampai 200 ppm sedikit aktif atau lemah. Jika nilai $\mathrm{IC}_{50}$ lebih dari 200 ppm tidak aktif (Molyneux, 2004). 
Kemampuan peredaman radikal DPPH pada ekstrak metanol daun belimbing hutan terkait dengan senyawa yang terkandung pada daun belimbing hutan. Aktivitas antioksidan senyawa fenolik dapat dihasilkan pada reduksi netralisasi radikal bebas yang mengawali proses oksidasi atau pada penghentian reaksi radikal berantai yang terjadi. Dimana senyawa fenolik merupakan kelas utama antioksidan yang berada dalam tumbuh-tumbuhan. Senyawa fenolik dapat meredam radikal bebas dengan menyumbangkan elektronya melalui atom hidrogen gugus hidroksil, radikal bebas senyawa-senyawa fenolik ini kemudian terstabilkan secara resonansi dan karena itu tak reaktif dibandingkan dengan kebanyakan radikal bebas lain sehingga dapat berfungsi sebagai antioksidan yang efektif. Sifat antioksidan dari flavonoid dan tanin berasal dari kemampuan untuk menstransfer sebuah elektron ke senyawa radikal bebas, dengan mekanisme tersebut flavonoid dan tanin memiliki efek yaitu menghambat peroksidasi lipid dan menekan kerusakan jaringan oleh radikal bebas (Endrini, Marsiati, Suherman, Fauziah, \& Asmah, 2016).
Semakin besar kandungan senyawa golongan fenoliknya maka semakin besar aktivitas antioksidannya (Rusli, Hardina, Muflihah, \& Rahmadani, 2015). Flavonoid dengan gugus hidroksi bebas mempunyai aktivitas penangkap radikal dan adanya gugus hidroksi lebih dari satu terutama pada cincin B akan meningkatkan aktivitas antioksidannya. Selain itu flavonoid merupakan senyawa pereduksi yang dapat menghambat banyak reaksi oksidasi. Flavonoid memiliki kemampuan sebagai antioksidan karena mampu mentransfer sebuah elektron kepada senyawa radikal bebas, dimana $\mathrm{R} \cdot$ merupakan senyawa radikal bebas, $\mathrm{Fl}-\mathrm{OH}$ merupakan senyawa flavonoid sedangkan $\mathrm{Fl}-\mathrm{OH} \bullet$ merupakan radikal flavonoid. Senyawa steroid, diduga salah satu senyawa yang meredam DPPH adalah steroid karena memiliki gugus $\mathrm{O}-\mathrm{H}$ pada kerangka dasar steroid yang memberikan aktivitas antioksidan.

Uji potensi antioksidan dilakukan dengan membandingkan $\mathrm{IC}_{50}$ fraksi etil asetat dan $\mathrm{IC}_{50}$ vitamin $\mathrm{C}$ yang dianalisis dengan menggunakan uji-t. Hasil analisis uji-t yang diperoleh oleh fraksi etil asetat dan vitamin $C$ dapat dilihat pada tabel 3.

Tabel 3. Hasil Analisis Uji-t

Paired Samples Test

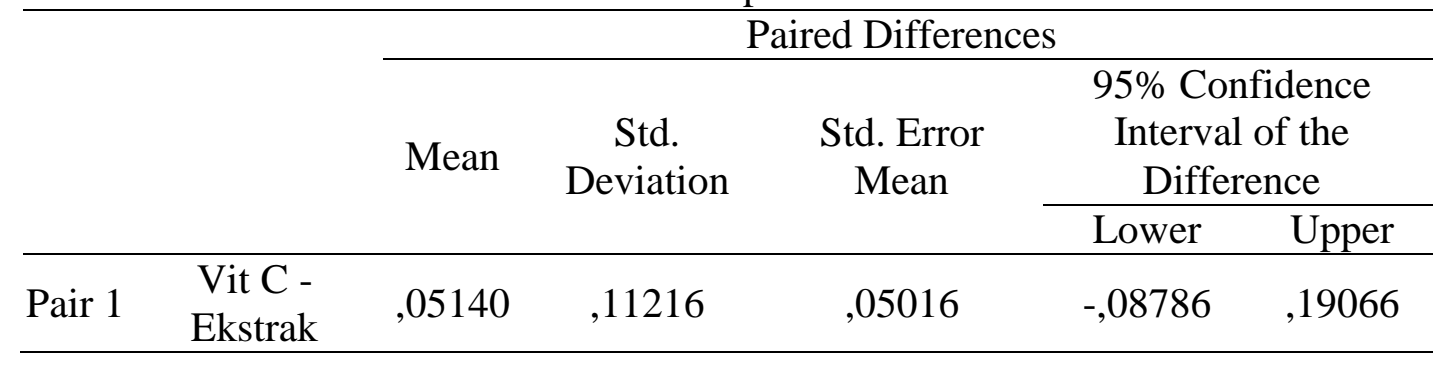

\begin{tabular}{rrrrr}
\hline \multicolumn{5}{c}{ Paired Samples Test } \\
\hline & & T & df & Sig. (2-tailed) \\
\cline { 3 - 6 } Pair 1 & Vit C - Ekstrak & 1,025 & 4 &, 363 \\
\hline
\end{tabular}


Berdasarkan gambar 1 diketahui diketahui ekstrak daun belimbing hutan dan vitamin $\mathrm{C}$ memiliki aktivitas antioksidan vitamin $\mathrm{C}$ lebih kuat dibandingkan aktivitas antioksidan ekstrak maupun masing-masing fraksi daun belimbing hutan, dan hampir sama untuk fraksi etil asetat. Hal ini dikarenakan vitamin $\mathrm{C}$ yang digunakan pada pengujian merupakan senyawa murni, sedangkan ekstrak dalam bentuk campuran senyawa yang kemungkinan memiliki khasiat yang beragam.

Berdasarkan hasil analisis uji-t, dapat disimpulkan bahwa antara fraksi etil asetat memiliki aktivitas antioksidan yang sebanding dengan Vitamin $\mathrm{C}$. Berdasarkan analisis uji-t yang dilakukan dapat dilihat bahwa nilai sig. ialah 0,363 yang dapat dikatakan bahwa nilai tersebut lebih dari 0,05 yang berarti antara fraksi etil asetat dengan vitamin $\mathrm{C}$ tidak ada perbedaan yang signifikan atau dapat diartikan bahwa fraksi etil asetat memiliki potensi sebagai antioksidan alami atau memiliki aktivitas antioksidan yang sama seperti vitamin $\mathrm{C}$.

\section{KESIMPULAN}

Berdasarkan penelitian dapat ditarik kesimpulan sebagai berikut:

1. Golongan metabolit sekunder yang teridentifikasi dalam ekstrak dan fraksi $n$-heksana, etil asetat dan $n$-butanol adalah golongan flavonoid, fenolik, tanin dan steroid pada fraksi $n$ heksana.

2. Aktivitas antioksidan ekstrak dari daun belimbing hutan adalah 15,06 ppm yang berarti bersifat sangat kuat sebagai antioksidan.

\section{DAFTAR PUSTAKA}

[1] Endrini, S., Marsiati, H., Suherman, J., Fauziah, O., \& Asmah, R. (2016). Aktivitas antioksidan dan efek sitotoksik ekstrak Kola (Cola nitida) pada kulter sel kanker hati (HepG-2). YARSI Medical Journal, 17(1), 040044.

[2] Es-Safi, N.-E., Ghidouche, S., \& Ducrot, P. H. (2007). Flavonoids: hemisynthesis, reactivity, characterization and free radical scavenging activity. Molecules, 12(9), 2228-2258.

[3] Febrina, L., Rusli, R., \& Muflihah, F. (2015). Optimalisasi Ekstraksi dan Uji Metabolit Sekunder Tumbuhan Libo (Ficus variegate Blume). Journal of Tropical Pharmacy and Chemistry, 3(2), 74-81.

[4] Herman, H. (2013). Aktivitas Antioksidan Beberapa Tumbuhan Obat Kalimantan Timur. Journal of Tropical Pharmacy and Chemistry, 2(2), 100-104.

[5] Jagetia, G. C., Venkatesha, V., \& Reddy, T. K. (2003). Naringin, a citrus flavonone, protects against radiation-induced chromosome damage in mouse bone marrow. Mutagenesis, 18(4), 337-343.

[6] Molyneux, P. (2004). The use of the stable free radical diphenylpicrylhydrazyl (DPPH) for estimating antioxidant activity. Songklanakarin J. Sci. Technol, 26(2), 211-219.

[7] Rusli, R., Hardina, M. P., Muflihah, F., \& Rahmadani, A. (2015). Profil Kromatografi Senyawa Aktif Antioksidan dan Antibakteri Fraksi n-Heksana Daun Libo (Ficus variegata Blume). Journal of Tropical Pharmacy and Chemistry, 3(2), 124-130. 